\title{
Hypolipidemia activity testing protocol or Guizotia Abyssinica Cass. seed oil: An Experimental study report
}

\author{
Research Article
}

\section{Bani Shashikala B1 ${ }^{*}$, Mallya Suma V², Bhat Sudhakara ${ }^{3}$}

1. Ph D Scholar, Department of Dravyaguna, 2. Associate Professor, Department of Dravyaguna, Sri Dharmasthala Manjunatheshwara College of Ayurveda Kuthpady, Udupi, Karnataka. India.

3. Research Officer, SDM Centre for Research in Ayurveda and Allied sciences Kuthpady, Udupi. India.

\begin{abstract}
Hyperlipidemia is characterized by increased level of cholesterol in the form of low-density lipoprotein (LDL), chylomicrons, VLDL. Guizotia abyssinica Cass (Ramtil) seeds are one among the sources for the edible oil, which are low in saturated fat, cultivated commonly in Northern part of Karnataka. Materials and Methods: Guizotia abyssinica Cass (Ramtil) seeds were collected authenticated seed oil extracted by Cold compression method. The experiment carried out in Wistar albino rats, inducing Hyperlipidemia by HFD, along with administration of test drugs (Guizotia abyssinica Cass. seed oil Single and double dose) and Standard Atorvastatin. Results \& Discussion: G. abyssinica Cass seed oil found to decrease total cholesterol and LDL. Even not showed significant increase in HDL. Protective action over the Liver, Kidney and heart through histopathological study exhibit its safety aspect. Conclusion: G. abyssinica Cass seed oil in HFD induced Hyperlipidemia found effective and safe.
\end{abstract}

Key Words: Guizotia abyssinica Cass, Hyperlipidemia, Experiment, Wistar albino rats, Cholesterol, Histopathology.

\section{Introduction}

The quest for finding the new safe and effective drug for hyperlipidemia in order to protect against cardiovascular disease is going to be a continuous process amongst the scientific fraternity. (1) Herbs form a source of food, as well as therapeutics when used properly. (2) Everyone looking for plant-based diet rich in fruit, vegetables, legumes with low saturated fat as an effective prescription for Hyperlipidemia. (3) These natural products, apart from lowering fat will also provide essential trace elements, nutrition to the body, thereby keep a person disease free and fit. (4) Guizotia abyssinica Cass (Ramtil) seeds are one among the sources for the edible oil seeds cultivated commonly in Northern part of Karnataka and consumed in the form of different dishes like chutney, oil source etc. (5) As per traditional claim these are said to be rich with nutritional factors, various trace elements, good for joint diseases and oil extracted out of these seed is said as a source healthy oil, best in heart diseases, obesity and other problems. (6)

Plasma cholesterol and triglycerides have clinical importance because of their major treatable risk factors for atherosclerosis and cardiovascular diseases. (7) Current life style disorders such as diabetes, obesity,

\section{* Corresponding Author:}

Mallya Suma V

Associate Professor, Department of Dravyaguna,

Sri Dharmasthala Manjunatheshwara College of

Ayurveda Kuthpady,

Udupi, Karnataka. India.

Email Id: sumamallya@gmail.com cardiovascular disease, hypertension are many times associated with abnormal lipid metabolism.(8) Hyperlipidemia is a condition in which the concentration of cholesterol or triglyceride-carrying lipoproteins in plasma exceeds an arbitrary normal limit. Oils and fats of herbal origin have proved better efficacy in lowering plasma cholesterol and triglycerides along with a protective effect on vital organs. (9)

Hence with this background, an experimental study designed to evaluate hypolipidemic activity of Guizotia abyssinica Cass seed oil on Wistar rats.

\section{Materials and Methods \\ Collection \& identification of sample}

Matured seeds of Guizotia abyssinica Cass. (Ramtil) were collected from Gadag district, seed oil extracted by Cold compression method through pressing the seeds in motorized Ghani. The extracted oil was decanted, filtrated, stored in air tight bottles and sample deposited at SDM center for Research in Ayurveda and Allied sciences. Medicinal dosage for Guizotia abyssinica Cass seed is not available in classics and other contemporary medicinal literature. Hence survey for traditional uses and dose was carried out and dose was fixed. (10)

\section{Hypolipidemic Activity}

Healthy adult Wistar albino rats, not less than 8 weeks old of both sex and weighing about $150-250 \mathrm{~g}$ were taken from animal house attached to SDM Centre for research in Ayurveda and Allied Sciences, Udupi. The experimental protocol was approved by IAEC with approval no. SDMCRA/IAEC/ DG-08. The animals 
were fed with normal diet, water and libitum and cholesterol solution throughout the study. They were acclimatized in the laboratory condition for one week prior to the experiment. (11)

\section{Posology:}

The human dose was decided by traditional survey on human consumption pattern and the same was converted into animals as per body surface area. Traditional dose for test drug Guizotia abyssinica Cass. (Ramtil) seed oil was $48 \mathrm{ml}$. And rat dose was calculated as $0.43 \mathrm{ml} / \mathrm{kg}($ Rat dose $=$ Human Dose $\times 0.018 \times 5=$ $0.43 \mathrm{ml} / \mathrm{kg}) .(12)$

Table 1. Grouping of Wistar Albino rats for experimental study

\begin{tabular}{|c|c|c|c|c|}
\hline $\begin{array}{l}\text { Sl. } \\
\text { No }\end{array}$ & Group & No & Drugs & Dose \\
\hline 1 & $\begin{array}{l}\text { Normal } \\
\text { Control }\end{array}$ & 6 & $\begin{array}{c}\text { Normal diet and } \\
\text { Water }\end{array}$ & $10 \mathrm{ml} / \mathrm{kg}$ \\
\hline 2 & $\begin{array}{l}\text { Positive } \\
\text { control }\end{array}$ & 6 & $\begin{array}{c}\text { High Fat diet ( HFD) } \\
\text { Cholesterol + } \\
\text { Vanspathi }\end{array}$ & $\begin{array}{c}0.5 \mathrm{ml} / \\
100 \mathrm{~g} \\
(40 \%)\end{array}$ \\
\hline 3 & Standard & 6 & Atorvastatin + HFD & $10 \mathrm{mg} / \mathrm{kg}$ \\
\hline 4 & $\begin{array}{c}\text { Single } \\
\text { Dose Test } \\
\text { group -I }\end{array}$ & 6 & $\begin{array}{c}\text { Guizotia abyssinica } \\
\text { Cass. seed oil + HFD } \\
\text { ( Single Dose) }\end{array}$ & $\begin{array}{c}0.43 \mathrm{ml} / \\
\mathrm{kg}\end{array}$ \\
\hline 5 & $\begin{array}{l}\text { Double } \\
\text { Dose Test } \\
\text { group - II }\end{array}$ & 6 & $\begin{array}{l}\text { Guizotia abyssinica } \\
\text { Cass. seed oil + HFD } \\
\text { (Double Dose) }\end{array}$ & $\begin{array}{c}0.86 \mathrm{ml} / \\
\mathrm{kg}\end{array}$ \\
\hline
\end{tabular}

\section{Experimental Protocol}

The selected Wistar albino rats were randomly grouped into 5 groups with 6 animals each. In group 1, only water and normal diet was administered without hyperlipidemic diet.

Group 2 serves as positive Control with HFD (High Fat Diet (HFD) i.e., 40\% Cholesterol suspended in Hydrogenated vegetable oil (Vanaspathi Ghee)) without drug. Group 3 received standard drug Atorvastatin $10 \mathrm{mg} / \mathrm{kg}$ with HFD. The $4^{\text {th }}$ and $5^{\text {th }}$ group received Guizotia abyssinica Cass seed oil Single Dose i.e. $0.43 \mathrm{ml} / \mathrm{kg}$ and $0.86 \mathrm{ml} / \mathrm{kg}$ along with HFD respectively. (13) The mode of administration was oral and test drugs were administrated in morning hours for 30 days(Table 1). On 31 st day, after overnight fasting, blood was collected from retro-orbital puncture and assigned for biochemical investigation then rats were sacrificed with ether overdose. The liver, kidney and heart were excised out from sacrificed animal, weighed and transferred to $10 \%$ formalin solution to tissue fixation prior to histopathological examinations. (14) Body weight of rat, weight of liver, heart and kidney were also measured. Biochemical Parameters like total cholesterol, triglyceride, HDL, LDL, VLDL, blood sugar, SGOT, SGPT, serum alkaline phosphate, total bilirubin, direct bilirubin also done.

The data obtained were analyzed by Student's t Test, one-way Anova, F test, followed by Dunnet's t-test using as the post hoc test were employed (Graph Pad 9.000). $\mathrm{P}$ value $<0.05$ were considered as statistically significant. (15) The data were presented as Mean \pm SEM.

\section{Results and discussion}

Table 2. Comparative effect of Guizotia abyssinca Cass seed oil on Body weight of Rats (gm)

\begin{tabular}{|c|c|c|c|c|c|c|}
\hline & & SEM & t'value & $\begin{array}{l}\text { P value } \\
(\mathrm{t} \text { test })\end{array}$ & $\begin{array}{l}\text { Changes in } \\
\text { body weight }\end{array}$ & $\begin{array}{l}\text { \% Change } \\
\text { (Annova) }\end{array}$ \\
\hline \multirow{2}{*}{ Normal control } & BT & $217.83 \pm 5.09$ & \multirow{2}{*}{2.937} & \multirow{2}{*}{$0.0324^{*}$} & \multirow{2}{*}{$0.516 \pm 0.18$} & \multirow{2}{*}{-} \\
\hline & AT & $218.35 \pm 4.97$ & & & & \\
\hline \multirow{2}{*}{ Positive control } & BT & $207.67 \pm 3.61$ & \multirow{2}{*}{17.20} & \multirow{2}{*}{$<0.0001 * *$} & \multirow{2}{*}{$2.067 \pm 0.12$} & \multirow{2}{*}{ 300.58@*** } \\
\hline & AT & $209.73 \pm 3.70$ & & & & \\
\hline \multirow{2}{*}{ Standard } & BT & $208.33 \pm 3.67$ & \multirow{2}{*}{9.56} & \multirow{2}{*}{$0.00028 * * *$} & \multirow{2}{*}{$1.067 \pm 0.11$} & \multirow{2}{*}{$48.38 \# *$} \\
\hline & AT & $209.4 \pm 3.59$ & & & & \\
\hline \multirow{2}{*}{ Single dose } & BT & $211.67 \pm 4.29$ & \multirow{2}{*}{6.162} & \multirow{2}{*}{$0.0016^{* *}$} & \multirow{2}{*}{$0.900 \pm 0.15$} & \multirow{2}{*}{$54.46 \# * *$} \\
\hline & AT & $212.57 \pm 4.23$ & & & & \\
\hline \multirow{2}{*}{ Double dose } & BT & $217 \pm 3.53$ & \multirow{2}{*}{5.606} & \multirow{2}{*}{$0.0025 * *$} & \multirow{2}{*}{$0.733 \pm 0.13$} & \multirow{2}{*}{$64.54 \# * * *$} \\
\hline & AT & $217.73 \pm 3.51$ & & & & \\
\hline
\end{tabular}

Data: Mean \pm SEM,@-Compared with Normal Control, \#-Compared with Positive Control*p $<0.05, * * p<0.001$ *** Extreme significant, ** Very significant, * significant, Decreased, Increased

Table.3 Comparative effect of Guizotia abyssinca Cass seed oil on Serum sugar (mg/dL)

\begin{tabular}{|c|c|c|}
\hline Groups & Mean \pm SEM & \% Change \\
\hline Normal control & $116.67 \pm 3.60$ & - \\
\hline Positive control & $141.5 \pm 1.98$ & $21.28 @$ \\
\hline Standard & $128.67 \pm 11.97$ & $12.83 \#$ \\
\hline Single Dose & $108.83 \pm 4.48$ & $23.09 \# *$ \\
\hline Double Dose & $136.33 \pm 9.53$ & $3.65 \#$ \\
\hline
\end{tabular}

Data: Mean \pm SEM, @-Compared with Normal Control, \#-Compared with Positive Control, ${ }^{*} \mathrm{p}<0.05$ Decreased, Increased 
Table 4. Comparative effect of Guizotia abyssinca Cass seed oil on Lipid profile (mg/dL)

\begin{tabular}{|c|c|c|c|c|c|c|c|c|c|c|}
\hline Groups & \multicolumn{2}{|c|}{ Normal Control } & \multicolumn{2}{|c|}{ Positive control } & \multicolumn{2}{|c|}{ Standard } & \multicolumn{2}{|c|}{ Single dose } & \multicolumn{2}{|c|}{ Double Dose } \\
\hline $\begin{array}{c}\text { Lipid } \\
\text { Parameter }\end{array}$ & $\begin{array}{c}\text { Mean } \\
\pm \text { SEM }\end{array}$ & $\%$ Change & $\begin{array}{l}\text { Mean } \\
\pm \text { SEM }\end{array}$ & $\%$ Change & $\begin{array}{l}\text { Mean } \\
\pm \text { SEM }\end{array}$ & $\%$ Change & $\begin{array}{l}\text { Mean } \pm \\
\text { SEM }\end{array}$ & $\%$ Change & $\begin{array}{c}\text { Mean } \pm \\
\text { SEM }\end{array}$ & $\%$ Change \\
\hline $\begin{array}{c}\text { S. } \\
\text { cholesterol }\end{array}$ & $\begin{array}{c}76.3 \\
\pm 7.64\end{array}$ & - & & & & & $\begin{array}{c}73.33 \\
\pm 3.17\end{array}$ & & & \\
\hline $\begin{array}{c}\text { Tri } \\
\text { glyceride }\end{array}$ & $\begin{array}{c}98.5 \\
\pm 6.29\end{array}$ & - & $\begin{array}{r}166 \\
\pm 43\end{array}$ & $\begin{array}{c}69.37 \\
@\end{array}$ & $\begin{array}{c}106.83 \pm 3 \\
82\end{array}$ & $\begin{array}{c}35.96 \\
\#\end{array}$ & $\begin{array}{c}332.5 \\
\pm 30.93\end{array}$ & & & $\begin{array}{c}115.56 \\
\# * *\end{array}$ \\
\hline LDL & $\begin{array}{c}4.28 \\
\pm 0.84\end{array}$ & - & $\begin{array}{c}22.83 \\
\pm 2.77\end{array}$ & & $\begin{array}{c}28 \\
\pm 4.55\end{array}$ & $\begin{array}{c}22.65 \\
\#\end{array}$ & $\begin{array}{c}5.78 \\
\pm 0.68\end{array}$ & & $\begin{array}{c}6.67 \\
\pm \quad 1.03\end{array}$ & $\begin{array}{l}70.78 \\
\# * * *\end{array}$ \\
\hline VLDL & $\begin{array}{r}19 . \\
\pm 1.2\end{array}$ & - & $\begin{array}{c}40.9 \\
\pm 9.84\end{array}$ & $\begin{array}{c}107.61 \\
@^{*} *\end{array}$ & $\begin{array}{c}21.5 \\
\pm 0.78\end{array}$ & $\begin{array}{c}47.43 \\
\#\end{array}$ & $\begin{array}{c}66.5 \\
\pm \quad 6.18\end{array}$ & $\begin{array}{c}62.59 \\
\# * *\end{array}$ & $\begin{array}{c}27.13 \\
\pm 1.44\end{array}$ & $\begin{array}{c}33.67 \\
\#\end{array}$ \\
\hline HDL & $\begin{array}{l}36.33 \\
\pm 4.27\end{array}$ & - & $\begin{array}{l}45.33 \\
\pm 4.84\end{array}$ & $\begin{array}{c}24.77 \\
@\end{array}$ & $\begin{array}{c}58.5 \\
\pm 5.97\end{array}$ & $\begin{array}{c}29.05 \\
\#\end{array}$ & $\begin{array}{r}11.66 \\
\pm 0.76\end{array}$ & $\begin{array}{c}74.28 \\
\# * * * *\end{array}$ & $\begin{array}{c}19.38 \\
\pm 4.14\end{array}$ & $\begin{array}{c}57.25 \\
\# * *\end{array}$ \\
\hline
\end{tabular}

Data: Mean \pm SEM, @-Compared with Normal Control, \#-Compared with Positive Control, ${ }^{*} \mathrm{p}<0.05,{ }^{* *} \mathrm{p}<0.001$ $* * *$ Extreme significant, ** Very significant, $*$ significant, Decreased, Increased

Table 5. Comparative effect of Guizotia abyssinca Cass seed oil on Liver function parametrs(mg/ dL)

\begin{tabular}{|c|c|c|c|c|c|c|c|c|c|c|}
\hline \multirow{2}{*}{$\begin{array}{c}\text { Groups } \\
\text { Parameter }\end{array}$} & \multicolumn{2}{|c|}{ Normal Control } & \multicolumn{2}{|c|}{ Positive control } & \multicolumn{2}{|c|}{ Standard } & \multicolumn{2}{|c|}{ Single dose } & \multicolumn{2}{|c|}{ Double Dose } \\
\hline & $\begin{array}{l}\text { Mean } \\
\pm \text { SEM }\end{array}$ & $\%$ Change & $\begin{array}{l}\text { Mean } \\
\pm \text { SEM }\end{array}$ & $\%$ Change & $\begin{array}{c}\text { Mean } \\
\pm \text { SEM }\end{array}$ & $\%$ Change & $\begin{array}{l}\text { Mean } \\
\pm \text { SEM }\end{array}$ & $\%$ Change & $\begin{array}{l}\text { Mean } \\
\pm \text { SEM }\end{array}$ & $\%$ Change \\
\hline $\begin{array}{c}\text { Total } \\
\text { bilirubin }\end{array}$ & $\begin{array}{c}0.53 \\
\pm 0.05\end{array}$ & - & $\begin{array}{c}0.58 \\
\pm 0.03\end{array}$ & $\begin{array}{c}9.43 \\
@\end{array}$ & $\begin{array}{c}0.5 \\
\pm 0.04\end{array}$ & $\begin{array}{c}13.79 \\
\#\end{array}$ & $\begin{array}{c}0.62 \\
\pm 0.07\end{array}$ & $\begin{array}{c}6.9 \\
\#\end{array}$ & $\begin{array}{c}0.68 \\
\pm 0.03\end{array}$ & $\begin{array}{c}17.24 \\
\#\end{array}$ \\
\hline $\begin{array}{c}\text { Direct } \\
\text { bilirubin }\end{array}$ & $\begin{array}{c}0.22 \\
\pm 0.03\end{array}$ & - & $\begin{array}{l}0.065 \\
\pm 0.01\end{array}$ & $\begin{array}{l}70.45 \\
@^{* *}\end{array}$ & $\begin{array}{c}0.07 \\
\pm 0.01\end{array}$ & $\begin{array}{c}7.69 \\
\#\end{array}$ & $\begin{array}{c}0.14 \\
\pm 0.04\end{array}$ & $\begin{array}{c}115.38 \\
\#\end{array}$ & $\begin{array}{c}0.17 \\
\pm 0.03\end{array}$ & $\begin{array}{c}161.54 \\
\# *\end{array}$ \\
\hline SGOT & $\begin{array}{c}82.17 \\
\pm 7.88\end{array}$ & - & $\begin{array}{l}153.67 \\
\pm 7.34\end{array}$ & $\begin{array}{l}87.01 \\
@ * * *\end{array}$ & $\begin{array}{c}86 \\
\pm 4.77\end{array}$ & $\begin{array}{l}44.04 \\
\# * * *\end{array}$ & $\begin{array}{r}149.83 \\
\pm 8.24\end{array}$ & $\begin{array}{c}2.5 \\
\#\end{array}$ & $\begin{array}{c}165.5 \\
+17.35\end{array}$ & $\begin{array}{c}7.7 \\
\#\end{array}$ \\
\hline SGPT & $\begin{array}{c}41.33 \\
\pm 5.17\end{array}$ & - & $\begin{array}{c}91 \\
\pm \quad 20.35\end{array}$ & $\begin{array}{c}120.18 \\
@\end{array}$ & $\begin{array}{c}55.67 \\
\pm 3.04\end{array}$ & $\begin{array}{c}38.82 \\
\#\end{array}$ & $\begin{array}{c}166.17 \\
\pm 19.53\end{array}$ & $\begin{array}{l}82.6 \\
\# * *\end{array}$ & $\begin{array}{c}91.83 \\
\pm 16.53\end{array}$ & $\begin{array}{c}0.91 \\
\#\end{array}$ \\
\hline ALP & $\begin{array}{c}537.33 \\
\pm 66.58\end{array}$ & - & $\begin{array}{r}1624.33 \\
\pm 263.38\end{array}$ & $\begin{array}{l}202.3 \\
@ * *\end{array}$ & $\begin{array}{c}529.33 \\
\pm 33.50\end{array}$ & $\begin{array}{l}67.41 \\
\# * * *\end{array}$ & $\begin{array}{r}1433.17 \\
\pm 280.40\end{array}$ & $\begin{array}{c}191.36 \\
\#\end{array}$ & $\begin{array}{c}786.17 \\
\pm 111.57\end{array}$ & $\begin{array}{c}51.6 \\
\# *\end{array}$ \\
\hline
\end{tabular}

Data: Mean \pm SEM, @-Compared with Normal Control, \#-Compared with Positive Control, ${ }^{*} \mathrm{p}<0.05, * * \mathrm{p}<0.001$ $* * *$ Extreme significant, ** Very significant, * significant, Decreased, Increased

Table 6. Post sacrifices comparative effect on Weight of organs (gm)

\begin{tabular}{|c|c|c|c|c|c|c|c|c|c|c|}
\hline Groups & Normal & Control & Positi & control & Star & dard & Sing & e dose & Doul & e Dose \\
\hline Organs & $\begin{array}{l}\text { Mean } \\
\pm \text { SEM }\end{array}$ & $\%$ Change & $\begin{array}{c}\text { Mean } \\
\pm \text { SEM }\end{array}$ & $\%$ Change & $\begin{array}{l}\text { Mean } \\
\pm \text { SEM }\end{array}$ & $\%$ Change & $\begin{array}{c}\text { Mean } \\
\pm \text { SEM }\end{array}$ & $\%$ Change & $\begin{array}{c}\text { Mean } \\
\pm \text { SEM }\end{array}$ & $\%$ Change \\
\hline Liver & $\begin{array}{c}8.62 \\
\pm 0.44\end{array}$ & - & $\begin{array}{c}7.10 \\
\pm 0.45\end{array}$ & $\begin{array}{l}17.63 \\
a^{* *}\end{array}$ & $\begin{array}{c}8.84 \\
\pm 0.21\end{array}$ & $\begin{array}{c}24.51 \\
\# * *\end{array}$ & $\begin{array}{c}8.94 \\
\pm 0.18\end{array}$ & $\begin{array}{c}25.92 \\
\# * *\end{array}$ & $\begin{array}{c}8.56 \\
\pm 0.19\end{array}$ & $\begin{array}{c}20.56 \\
\#^{*}\end{array}$ \\
\hline Kidney & $\begin{array}{c}1.59 \\
\pm 0.03\end{array}$ & - & $\begin{array}{c}1.68 \\
\pm 0.10\end{array}$ & $\begin{array}{l}5.66 \\
\text { @ ** }\end{array}$ & $\begin{array}{c}2.09 \\
\pm 0.12\end{array}$ & $\begin{array}{l}24.4 \\
\# * * *\end{array}$ & $\begin{array}{c}1.81 \\
\pm 0.07\end{array}$ & $\begin{array}{c}7.74 \\
\#\end{array}$ & $\begin{array}{c}1.81 \\
\pm 0.09\end{array}$ & $\begin{array}{c}7.74 \\
\# *\end{array}$ \\
\hline Heart & $\begin{array}{c}0.87 \\
\pm 0.03\end{array}$ & - & $\begin{array}{c}0.83 \\
\pm 0.06\end{array}$ & 4.6 & $\begin{array}{c}0.99 \\
\pm 0.06\end{array}$ & $\begin{array}{c}19.28 \\
\#^{*}\end{array}$ & $\begin{array}{c}0.99 \\
\pm 0.03\end{array}$ & $\begin{array}{c}19.28 \\
\#\end{array}$ & $\begin{array}{c}0.99 \\
\pm 0.01\end{array}$ & $\begin{array}{c}19.28 \\
\#^{*}\end{array}$ \\
\hline
\end{tabular}

Data: Mean \pm SEM, @-Compared with Normal Control, \#-Compared with Positive Control, * $\mathrm{p}<0.05,{ }^{*} \mathrm{p}<0.001$ $* * *$ Extreme significant, $* *$ Very significant, $*$ significant, Decreased, Increased

Hyperlipidemia is the condition of elevated lipid levels due to intake of high fat diet. (16) Body weight is increased by imbalance of energy consumption and intake. The assessment of Lipid levels are the prime objective parameters. Usually Serum cholesterol, Triglycerides, LDL, VLDL are elevated but the HDL will be decreased in Hyperlipidemia. (17)

\section{Effect Over the body weight}

All the animals (Control and experimental) during the experimental period showed no observable changes. The weights of the rats were significantly increased in all groups. Gain in body weight indicates normal progressive health status of an organism. Significant decrease observed in test drugs (Single Dose and double dose) comparing to the positive control group. The double dose showed the magnitude of decreased body weight while therapeutic dose showed the attenuated body weight in comparison to positive control group (Table 2).

\section{Effect over the Lipids}

The data related to the Lipid profile in positive control group showed the significant increase in the parameter's indicative of the manifestation of the disease. The experimental data for test drug therapeutic dose (single dose) and double dose showed the significant decrease in Serum cholesterol and LDL cholesterol indicating effectiveness in hyperlipidemia. The triglycerides were increased in single dose group and decreased in double dose significantly. VLDL is significantly increased in single dose test drug group 
meanwhile decrease observed in double dose test drug group which has no significance. HDL also found significantly decreased in the both test drug group (Table 4).

\section{Effect over Serum sugar}

The serum sugar is found increase in positive control in comparing to normal with no significance; single test drug group showed the significant decrease and double dose showed marginal decrease with no significance (Table 3). The test drug is capable of hibernate the increase of serum sugar.

\section{Effect over the Liver profile}

The data related to liver function parameters have showed the significant differences compared to normal control group. This indicates the HFD induced hyperlipidemia is responsible for the increased Liver activity. Bilirubin levels are also found to be elevated (Table 5).

\section{Effect over the ponderal changes in Liver, Kidney and Heart}

- Liver: The data for liver in Positive control group has the significant decrease in the weight compared to the Normal control. Both test drug group showed the significant increase in the weight. The exact relation between the liver weight and hyperlipidemia is not known. Fatty degenerative changes if severe may lead to loss of liver weight. Its reversal would indicate attenuation of degenerative changes. The histopathological changes observed in the liver of standard group, are mild to severe degeneration. But the both the single dose and double dose test drug group showed mild degeneration compared to positive control and showed protection for some extent.

- Kidney: Histopathological observation revealed that positive control group has mild degeneration while the single dose test drug group showed the attenuated change compared to positive control. Double dose test drug group has not showed any degenerative change indicating the mild protection.

- Heart: Histopathological examination heart of positive control and single dose test drug group showed the mild degenerative changes. Double dose test drug showed the mild protection (Table 6).

The test drug Guizotia abyssinica Cass Seed oil contains the fatty acids like of triglycerides, lauric, palmitic, palmitoleic, stearic, oleic, linoliec and arachidic acids as per literature. The linoleic acid content was approximately $55 \%$. (18) The present experimentation has objective to evaluate hypolipidemic activity in HFD induced hyperlipidemia. Being the test drug itself the source of fatty acids is responsible for decrease the total cholesterol and LDL. Contrary not showed the significant increase in HDL. The protective action over the Liver, Kidney and heart also exhibits the safety aspect.

\section{Conclusion}

Guizotia abyssinica Cass seed oil in HFD induced Hyperlipidemia found effective, safe as per present study protocol. Therapeutic dose found effective to regulate lipid and also shown protective action over liver and kidney. As oils and fats are also a part of diet, these can be substituted as healthy source of diet.

\section{Acknowledgements}

Authors are grateful to President Dr. D Veerendra Heggade and Dr. B. Yashoverma, Secretory SDM Educational society for constant support. Authors are thankful to former principal Dr. G Srinivasa Acharaya and current principal Dr. Mamatha KV, for all support rendered.

\section{Reference}

1. Ram et al., Ayurvedic management of dyslipidemiaa case study. EJPBS. 2018,5(1); 906-8.

2. Payal Gupta et al., Ayurvedic Management of Hyperlipidemea and obesity. IAMJ. 2016, 4(2); 1-5.

3. Tantawy W.H.E.L- and Temraz A, Natural products for controlling Hyperlipidemea- review. Archives of Physiology and Biochemistry. 2018, 3-10

4. Sharma RK, Arora Rajesh, Herbal drugs a twenty first century perspective. Jaypee brothers Medical Publishers(P) Ltd. 2006; 1(1); 422-26

5. Bani Shashikala, Mallya Suma V, Prabhu Suchitra., Quality control constraints of Guozotia abyssynica Cass. Source of medicinally used edible oil seeds. The Journal of Phytopharmacology. 2018, 7(5); 431-436.

6. Bani Shashikala, Mallya Suma., Nutritional factor and antioxidant potential of Guizotia abyssinica cass. Popularly used edible seed oil. World Journal of Pharmaceutical research. 2019, 8(12); 1194-98

7. Waheeb DM. Alharbi. Plasma cholesterol and triglycerides in obese smokers. Int. J. Biotech. 2011, 8(3); 433-35

8. Manjiri A Nadakarni et al., Randomized placebocontrolled trial of Mustadi Ghana vati in Hyperlipidemia. Ayu. 2010, 31(3); 287-93

9. Niharika verma. Introduction to Hyperlipidemea and its treatment- a review. Int J Curr Pharm Res. December 2016, 9(1); 6-14

10. Maruthappan V, Shree KS., Hypolipidemic activity of Haritaki(Terminalia chebula) in atherogenic diet induced hyper lipidemic rats; Journal of Advanced Pharmaceutical Technology and Research. 2010, $1(2) ; 229-35$

11. Shivaprasad NP et al. Avrishya Dravya; Peril to Fertility; An experimental data of Shigru beeja(Moringa oliefera Lam.) on spermatogenesis modulation activity. JBSO. 2015, 3(5); 216-20

12. Vijender Singh, Ashok Chaudhary, Gunjan. Antihyperlipidemic activity of Picrorrhiza kurroa Royle ex Benth Roots. IJDDR. 2012, 4(3); 88-94

13. Rajmohan, Suma Venkatesh Mallya et al. AntiHyperlipidemic activity of Vateria indica Linn. Seed butter in high fat diet induced Hyperlipidemia in Rats. J Ayu Med Sci. 2017, 2(3); 234-9 
14. Prasad Ucchangi, Ravishanakar B, Sudhakara Bhat, Mallya Suma V, Mundugaru Ravi. Saftey profile of Soothshekhar rasa, commonly used herbomineral product in Ayurveda. WJPR. 2018, 8(1);1176-84

15. Romain- Daniel Gosselin., Guidelines on statistics for researchers using laboratory animals; the essentials; Laboratory animals. 2019, 53(1); 28-42

16. Saravanakumar et al., Hypolipidemic activity of Sesbania grandiflora in triton wr-1339 induced hyperlipidemic rats. International Journal of Phytomedicine 2 (2010); 52-58

17. Sowmya A, Ananthi T. Hypolipidemic activity of Mimosa pudica Linn on Butter Induced Hyperlipidemia in Rats. Asian J. Res. Pharm. Sci. 2011,1(4); 123-126.

18. Anonymous. The Wealth of India - A Dictionary of Indian Raw Materials. 1st ed. New Delhi; Publications \& Information Directorate, CSIR;1985. 